\title{
Araştırma Makalesi https://doi.org/10.33484/sinopfbd.494656 \\ Püskürtme Betonda Kimyasal Katkı Miktarının Priz Süresine ve Beton Basınç Dayanımına Etkisi
}

\author{
Ali Öztürk ${ }^{a}$, Celalettin Başyiğit ${ }^{b^{*}}$ \\ ${ }^{a 1}$ Süleyman Demirel Üniversitesi, Fen Bilimleri Enstitüsü, İnşaat Mühendisliği ABD, 32200, Isparta \\ ${ }^{b 2}$ Süleyman Demirel Üniversitesi, Mühendislik Fakültesi, Inş̧aat Mühendisliği Bölümü, 32200, Isparta
}

\section{$\ddot{\mathbf{O} z}$}

$\mathrm{Bu}$ çalışmada, tünellerde kullanılan püskürtme betona eklenen priz hızlandırıcı katkı malzemesi oranının optimum değeri araştırılmıştır. \%5, \%8, \%10 oranlarında katkı kullanılarak ve katkı kullanılmadan, püskürtme betonu için çimento priz hızlandırıcı katkı uyum testi ve beton basınç dayanım deneyleri yapılmıştır. Yapılan deneylerde, su/çimento oranı, çimento miktarı ve tipi, agrega miktarı ve özellikleri sabit tutulmuştur. Priz hızlandırıcı katk1 uyum testi için toplamda 8 adet numune hazırlanmıştır. Katkısız kontrol numuneleri, \%5 katkı içeren numuneler, \%8 katkı içeren numuneler ve \%10 katkı içeren numuneler hazırlanarak elde edilen sonuçlar değerlendirilip katkı miktarının priz süresine ve beton basınç dayanımına etkisi incelenmiştir. Deneylerde kullanılan \%10 priz hızlandırıcı katkı miktarı, priz süresini oldukça kısaltmaktadır ve bu denli bir kısalma uygulama zorluklarına yol açmaktadır. \%5 priz hızlandırıcı katkı malzemesi kullanılması durumunda, priz süresi değerlendirme tablosuna göre ilk priz süresi kabul edilebilir olarak değerlendirilmiştir. \%8 priz hızlandırıcı katkı miktarı kullanıldığında ise optimum sonuç elde edildiği gözlemlenmiştir.

Anahtar Kelimeler: Tüneller, püskürtme beton, priz hızlandırıcı katkılar, basınç dayanımı.

\section{The Effect of Chemical Additive Amount on Shot Concrete and Concrete Compressive Strength}

\begin{abstract}
In this study, the optimum value of the ratio of added set accelerating admixture used in the tunnel spraying concrete was investigated. 5\%,8\%, 10\% of the use of the set accelerating admixture and additives without using set accelerating admixture, cement concrete accelerator admixture compliance test and concrete compressive strength tests were made. In the experiments, water / cement ratio, amount and type of cement, aggregate amount and properties were kept constant. A total of 8 samples were prepared for the fit acceleration additive compliance test. Pure control samples, samples containing $\% 5, \% 8$ and $\% 10$ set accelerator were prepared and the results obtained were evaluated and the effect on the concrete setting time and concrete compressive strength were investigated. The amount of $10 \%$ set accelerating additives used in the experiments significantly shortens the setting time, and such shortening leads to application difficulties. In case of using 5\% set accelerating additives material, the initial setting time is considered to be acceptable according to the
\end{abstract}

\footnotetext{
* Sorumlu Yazar: ORCID ID: orcid.org/0000-0003-0084-1320

e-mail: celalettinbasyigit@sdu.edu.tr
}

Received: 10.12 .2018

Accepted: 17.05.2019 
setting time table. When the $\% 8$ accelerator additive amount is used, it is observed that the optimum result is obtained.

Keywords: Tunnels, sprayed concrete, set accelerating admixture, compressive strength.

\section{Giriş}

Tüneller ve portaller inşa edilirken püskürtme beton (shotcrete) sıkça kullanılan bir malzemedir. Püskürtme beton; normal betona göre daha ince taneli ve daha yüksek çimento oranlı özel tasarım betonun, yüksek basınçlı pompa yardımı ile püskürtülmesiyle uygulanır. Amerikan Beton Enstitüsü (ACI: American Concrete Institue), 1966 yılında püskürtme betonun tanımını; "Bir hortumla taşınarak bir yüzey üzerine basınçlı hava yardımıyla yüksek hızla püskürtülen beton ya da harç karışımı" olarak nitelendirmiştir [1]. Türk standartları Enstitüsü'nün tanımlamasına göre ise püskürtme beton; onarım veya yapım amacı ile önceden hazırlanmış olan betonun hava basıncı ile yüksek hızla uygulama yüzeyi veya uygulama alanına püskürtülerek elde edilen betondur [2].

Geleneksel betona göre kalıp gerektirmeden yerleştirilmesi ve özel katkılar yardımıyla hemen dayanım kazanmaya başlayarak taşıyıcılığını yerine getirmeye başlaması gibi özellikleri nedeniyle birçok alanda yaygın olarak kullanılmaktadır. Püskürtme betonda taşıma, yerleştirme, sıkıştırma aşamaların bir anda yapılması, uygulamanın hızlı yapılabilir olması, farklı çalışma ortamlarında farklı boyut ve kesitlerde istenilen şekilde uygulanabilir olması, kalıp gerektirmediğinden malzeme ve işçilik tasarrufu yapılması gibi etkenler de yaygın kullanılma sebeplerindendir [3]. Püskürtme beton, özellikle kalıp imalatının zor olduğu, kalıp maliyetlerinin ekonomik olmadiğ 1 , betonun yerleştirilme ve sıkıştırmasının güç olduğu yerlerde, betonun ince bir tabaka olarak uygulanması gereken yerlerde kullanılmasının uygundur [4].

Püskürtme beton, kullanım alanına göre 2 kategoride değerlendirilebilir. Bunlar yeraltı ve yer üstü kullanımlardır. Yeraltı kullanımda en sık kullanılan yer tünel inşaatlarıdır. Metro, karayolu gibi inşaatlarda sıkça karşılaştığımız bir sanat yapısı olan tünellerde, oldukça önemli bir uygulamadır. Ayrıca yeraltı madenleri, yeraltı depoları gibi alanlarda da kullanılmaktadır. Püskürtme beton yer üstünde ise özellikle yol şevleri gibi son şeklini almış yapılarda duraylılı̆̆ sağlamak ve kaplamak amaciyla kullanılmaktadır. Püskürtme betonun kazı işlerinde yaygın kullanılmasının sebebi, kazı yapılan yüzeylerde kazının hemen 
ardından kolayca uygulanabilir olmasıdır [5].

Geleneksel betondan farklı olarak, püskürtme betonun taşınması ve yerleştirilmesi işlemi basınçlı hava ile yapılmaktadır. Püskürtme beton kuru karışım ve yaş karışım olmak üzere 2 ayrı yöntem ile uygulanabilmektedir. Kuru yöntemde, tüm malzemeler kuru ortamda hazırlanıp basınçlı hava ile püskürtme ucuna iletilmektedir. Hidratasyon için gerekli su karışıma püskürtme ucundan basınçlı olarak verilmektedir. Kuru karışımda püskürtme beton karışımına eklenecek olan katk1 malzemesi varsa; katkı malzemesi sıvı ise su ile beraber püskürtme ucundan, katı ise püskürtme beton makinesinin içerisinden karışıma eklenmektedir. Uygulama yapılırken çimentonun agregayı iyice sarması amacıyla kuru karışımdaki agrega ağırlığının \%3-8'i kadar nem içermesi gerekmektedir [3]. Püskürtme beton 1970 y1lına kadar yalnızca kuru sistem olarak uygulanmıştır. $\mathrm{Bu}$ tarihte yaş sistem devreye girmiş ancak yüksek su-çimento oranı kullanılması beton dayanımında düşme yarattığından yaygın uygulama görülmemiştir. $\quad 1975$ 'de silikat ve plastisiteyi artırıcı katkıların püskürtme betonda başarıyla uygulanması yüksek kapasitede uygulanabilen yaş sisteme yüksek dayanım kazandırmış ve bu metotta yaygın olarak kullanılmaya başlanmıştır [6]. Yaş püskürtme beton uygulamasında ise, karışım normal betonda olduğu gibi hazırlanarak beton pompasina beslenir, pompa ile hidrolik olarak iletim borusundan püskürtme ucuna kadar ilerletililir ve püskürtme beton yüzeye uygulanmaktadır. Yaş karışım yönteminde karışıma ilave edilen priz hızlandırıcı katkılar sıvı halde olduğundan püskürtme ucuna ilave edilmektedir.

Püskürtme beton, normal betondaki gibi iri - ince agrega, çimento, su ve katkı maddeleri bileşenlerinden oluşan bir karışımdır. Püskürtme beton karışımlarında, beton bileşenleri betonun mekanik özellikleri ile doğrudan ilgili olduğu için malzeme bileşenleri ve bileşen özelliklerini bilmek oldukça önemli bir husustur. Püskürtme beton uygulamalarinda genellikle Portland çimentosu kullanılmaktadır [3]. Hammaddeleri farklı kaynaklardan gelen çimentoların priz süreleri farklı1lık gösterir. Doğal olarak bu durum katlı maddesinin etkinliğinde de kendini gösterecektir [7]. Genel kural olarak püskürtme betonda kullanılan çimentonun trikalsiyum alüminat $\left(\mathrm{C}_{3} \mathrm{~A}\right)$ oranı ve özgül yüzeyinin yüksek olması, böylece priz hızlandırıcilarla birlikte hidratasyonu hızlı 
gelişen ve erken dayanım kazanan tipte olması istenmektedir [8]. Özel kullanım isteklerine bağlı olarak sülfatlı su bulunan ortamda sülfata dirençli çimento veya kaplamanın erken dayanım kazanması istenen durumlarda hızlı sertleşen çimento gibi farklı tipte çimentolar kullanılabilir [3]. Kullanılan çimento miktarı, püskürtme betondan istenen mekanik özelliklere bağlı olarak değişebilmektedir [9]. Karışımda kullanılacak olan su için çok sıkı kurallar bulunmamaktadır. Bununla beraber yă̆, asit, organik madde gibi suyun kalitesini bozan ve suyu kirleten maddeler içermemesi istenmektedir. İçme suyu olarak kullanılabilen su karışım için uygundur. Agrega, beton malzemesinin ana taşıyıcı iskeletini oluşturmaktadır. Dane çap1 4 mm'ye kadar olan “ince agrega", 4 mm'den büyük olanı ise "iri agrega" olarak tanımlanmaktadır [10]. Kullanılan agrega malzemesi dayanıml, ayrışma ve aşınmaya dirençli olmalı, içerisinde kil, silt, alkali ve organik madde bulundurmamalıdır. Agrega dane boyut dağılımı açısından sahip olması gereken özellikler ve bunlara dair sınır değerler Karayolları Teknik Şartnamesinde verilmiştir [11].

Püskürtme beton uygulamasinda en büyük agrega çapı, kullanılan donanım ve iletim borusu çapı ile sınırlıdır. Püskürtme beton uygulamasinda

agrega granülometresi hakkında dikkat edilmesi gereken noktalar aşağıda belirtilmiştir:

- Maksimum dane boyutu 8 - $10 \mathrm{~mm}$ aralığında olmalıdır. Agrega $12 \mathrm{~mm}$ 'den büyük dane içermemeli, $8 \mathrm{~mm}$ 'den büyük malzeme miktarı ise \%10'u geçmemelidir.

- Her elek aralığındaki malzeme miktarı, dane boyut dağılımında kesikliğe yol açabileceği için \%30’u geçmemelidir.

- İnce malzeme miktarı dayanım ve işlenebilirlik üzerinde etkilidir. 0,125 mm'den ince malzeme miktarı en az \%4-5 olmalı, \%8-9'u geçmemelidir [12].

- Betonun kütlece yaklaşık \%70-80'ini agregaların oluşturduğu göz önüne alındığında; agregaların sıcaklığı, sıcak ya da soğuk hava koşullarında beton üretiminde taze beton sicaklığının en önemli belirleyicisidir. $\mathrm{Bu}$ nedenle taze beton sıcaklığı, plent çıkışında $30{ }^{\circ} \mathrm{C}$ 'yi ve yerine yerleştirilirken de $32{ }^{\circ} \mathrm{C}$ 'yi aşmayacak şekilde agreganın 1sıtılması ya da soğutulması, karma suyuna buz katılması (beton içinde buz parçaları olmadan) gibi önlemler alınmalıdır.

Püskürtme betonun granülometrik birleşimi ve maksimum agrega boyutu ise normal betonarme betonundan farklıdir. Püskürtme betonda kullanılacak agregaların granülometrisi Karayolları 
Teknik Şartnamesinde verilen değerlere uygun olmalıdır [11].

Püskürtme betonda, istenilen özellikler sağlanması amacıyla bazı katkı malzemeleri kullanılmaktadır. Kullanılacak olan katk1 malzemeleri, betonu fiziksel ve mekanik özelliklerine etki edeceği için bu katk1lı betonlar laboratuarda test edilmesi gerekmektedir. Priz hızlandırıcı katkılar, kuru ve yaş püskürtme beton uygulamalarında en sik kullanılan katkı malzemesidir. $\mathrm{Bu}$ katkılar priz süresini kısaltmak, erken dayanımı artırmak, püskürtme betonun yüzey yapışma kalitesini iyileştirmek ve geri sıçramayı azaltmak amaciyla kullanılmaktadır. Priz hızlandırıcılar toz veya sıvı şeklindedir. Katkı malzemesinin miktarı, çimento ağırlığının \%3 - \%10’u arasında olması önerilmektedir [13]. Priz hizlandirıcı katkılar karışımın priz başlangıcını kısalttığından aynı zamanda geri sıçramayı da azaltır ve bir defada kalın bir tabaka oluşturabilmeyi sağlar. Fakat priz hızlandırıc1 katkılar betonun nihai (28 günlük) basınç dayanımını \%35'e varan oranla azaltmaktadırlar [14]. Püskürtme betonda kullanılan priz hızlandırıcı katkı türleri; alkali içeren priz hızlandırıcılar ve alkali içermeyen priz hızlandırıcılardır [15].

\section{Materyal ve Metot}

Püskürtme betonu için yapılan deneylerden bir tanesi çimento - priz hızlandırıcı katkı uyum testi deneyidir. $\mathrm{Bu}$ deney, priz hızlandırıcı katılmış çimento harcının TS EN 196-1 standardında açıklandığı şekilde, priz başlangıcı - priz bitişinin belirlenmesi amacıyla yapılan bir deneydir. Yapılış amacı çerçevesinde harcın hızlı hazırlanması gerekmektedir. Karışımda uygulanması öngörülen oranlardaki (su/çimento) ve katkı oranında suyun ve hızlandırıcının çimentoya ilave edilmesinden sonra harç 15 saniye karıştırılmakta ve 25 . saniyeden sonra vicat iğnesiyle priz başlangıç ve priz bitiş süresi belirlenmektedir. Sivi hizlandırıcı kullanılan deneylerde katkı suya katılmakta ve su/çimento oranı hesabında su olarak kabul edilmektedir. Priz başlangıcı 5 dakika, priz bitişi ise 13 dakikadan küçük ise priz hızlandırıcı katkı uygun olarak nitelendirilmektedir [15].

Yapıdaki betonu karakterize etmesi amacıyla boy/çap oranı, 1,0'dan farklı olarak alınan karot numuneleri başlık yapıldıktan sonraki boy/çap= 1,0 olacak şekilde kesilerek düzeltildikten sonra basınç dayanım testine tabi tutulmuştur. Tablo 1'de püskürtme beton için basınç dayanım sınıfları ve kalite kontrol kriterleri verilmiştir. 
C 20/25 MPa sınıfindaki püskürtme

Tablo 1'e uygun yapılmıştır.

betonun basınç dayanımının gelişim hızı,

Tablo1. Püskürtme beton için basınç dayanım sınıfları ve kalite kontrol kriterleri [11]

\begin{tabular}{|c|c|c|c|c|}
\hline \multirow{2}{*}{\multicolumn{3}{|c|}{$\begin{array}{c}\text { Beton sınıfları } \\
\text { Karakteristik basınç dayanımı } \\
\left(\mathrm{f}_{\mathrm{ckp}}\right)(\mathrm{MPa})\end{array}$}} & \multirow{2}{*}{\multicolumn{2}{|c|}{$\begin{array}{l}\text { Püskürtme betondan alınacak karot numunede } \\
\text { dayanım yönünden ( } 28 \text { günlük) aranacak kalite } \\
\text { kontrol kriterleri } \\
\text { Karot numune Boy }(\mathrm{H})=100 \mathrm{~mm} \text {, Çap }(\mathrm{D})=100 \\
\text { mm Silindir }\end{array}$}} \\
\hline & & & & \\
\hline $\begin{array}{c}\text { Basınç } \\
\text { dayanım } \\
\text { sinıfları }\end{array}$ & $\begin{array}{c}\mathrm{D}=150 \mathrm{~mm}, \\
\mathrm{H}=300 \mathrm{~mm}, \\
\text { Silindir }\end{array}$ & $\begin{array}{c}\mathrm{A}=150 \\
\mathrm{~mm} \\
\mathrm{Küp}\end{array}$ & $\begin{array}{c}\text { Bireysel } \\
\text { minimum } \\
\text { dayanım }(\mathrm{MPa})\end{array}$ & $\begin{array}{c}3 \text { adet numuneden oluşan grubun } \\
\text { ortalama minimum dayanımı } \\
(\mathrm{MPa})\end{array}$ \\
\hline C 20/25 & 20 & 25 & 19,0 & 21,5 \\
\hline C 25/30 & 25 & 30 & 22,5 & 25,5 \\
\hline C 30/37 & 30 & 37 & 28,0 & 31,5 \\
\hline C $35 / 45$ & 35 & 45 & 34,0 & 38,5 \\
\hline $\mathrm{C} 40 / 50$ & 40 & 50 & 37,5 & 42,5 \\
\hline C 45/55 & 45 & 55 & 41,5 & 47,0 \\
\hline C 50/60 & 50 & 60 & 45,0 & 51,0 \\
\hline
\end{tabular}

Yapılan deneylerde, tünellerde kullanılan püskürtme betonda alkali içermeyen sıvı priz hızlandırıcı katkılar değerlendirilmiştir. TS 11747 standardına göre, püskürtme beton için kullanılabilecek katkılar; priz hızlandırıcı, hava sürükleyici, su azaltıcı ve geciktirici katkılar olarak verilmiştir [2]. $\mathrm{Bu}$ deney çalışmasında, püskürtme betonlarda en çok kullanılan priz hızlandırıcı katkıların beton dayanımına ve priz süresine olan etkileri incelenmiştir. Püskürtme beton karışımı hazırlanırken ıslak ve kuru olmak üzere iki metot bulunmaktadır. $\mathrm{Bu}$ deney kapsaminda uygulanan metot islak metottur. Alkali içermeyen priz hızlandırıcı katk1 malzemesi üreticisinden alınan bilgiler doğrultusunda, su/bağlayıcı oranı 0,5'den küçük olmalı, tercihen 0,45 olmalıdır. Düşük su/bağlayıcı oranı, daha yüksek erken dayanım, daha iyi durabilite, daha düşük priz hızlandırıcı sarfiyatı ve baş üstü uygulamalarında daha kalın katmanlar halinde uygulama imkânı sağlamaktadır [13]. Yapılan deneyler 0,45 oranı kullanılarak yapılmıştır. Priz hızlandırıcı katkının dozajı, EFNARC Avrupa Püskürtme Beton Şartnamesi (1996) Ek 1, Madde 6.3'te belirtilen sınırlar dikkate alınarak belirlenmektedir [16]. Tablo 2'de priz değerlendirme değerleri verilmiştir. Priz hızlandırıcı katkı malzemesi kullanım miktarı, su/ bağlayıcı oranı, sicakl1k (betonun ve ortamın), çimento reaktivitesi, uygulanacak püskürtme beton kalınlığı, priz süresi ve 
erken dayanım gelişimine bağlıdır. Katkı, normal koşullarda bağlayıcı ağırlığının üreticisinden alınan bilgiler kapsamında \%4-10’u mertebesinde kullanılmaktadır.

Tablo 2. Priz değerlendirme tablosu

\begin{tabular}{|l|l|l|l|}
\hline İlk Priz & Son Priz & 24 sa Dayanım & Değerlendirme \\
\hline$<2$ dakika & $<6$ dakika & $>15 \mathrm{MPa}$ & İyi \\
\hline $2-5$ dakika & $8-13$ dakika & $10-15 \mathrm{MPa}$ & Kabul edilebilir \\
\hline$>5$ dakika & $>13$ dakika & $<10 \mathrm{MPa}$ & Kabul edilemez \\
\hline
\end{tabular}

Yapılan bazı çalışmalarda, artırılırsa \%50 mertebelerine ulaşabileceği püskürtme betonda kullanılan priz hızlandırıcı katkı malzemelerinin 28 gözlemlenmiştir [17].

Tablo 3'te deneylerde kullanılan günlük basınç dayanımlarında, referans karışımlara göre \%20 - \%25 oranında azalmaya neden olduğu görülmektedir. Bu püskürtme betona ait karışım hesabı ve priz hızlandırıcı katkı malzemesinin özellikleri yer almaktadır. dayanım azalışının, katkı miktarı daha da

Tablo 3. Püskürtme Beton Karışım Hesabı ve Malzeme Özellikleri

\begin{tabular}{|c|c|c|}
\hline Çimento Cinsi & \multicolumn{2}{|c|}{ CEM-I 42,5 } \\
\hline Çimento Miktarı & \multicolumn{2}{|c|}{$475 \mathrm{~kg} / \mathrm{m}^{3}$} \\
\hline Katk1 Cinsi & \multicolumn{2}{|c|}{ Priz Hızlandırıcı BASF SA-160 } \\
\hline \multirow{3}{*}{ Katkı Miktarı } & \multicolumn{2}{|c|}{$\% 5$} \\
\hline & \multicolumn{2}{|c|}{$\% 8$} \\
\hline & \multicolumn{2}{|c|}{$\% 10$} \\
\hline Su Miktarı & \multicolumn{2}{|c|}{$213 \mathrm{~kg} / \mathrm{m}^{3}$} \\
\hline Agrega Taş Ocağ 1 & \multicolumn{2}{|c|}{ Karpuzkaya Taş Ocağ1 } \\
\hline Maksimum Agrega Boyutu & \multicolumn{2}{|c|}{$12,5 \mathrm{~mm}$} \\
\hline \multirow[b]{2}{*}{ Agrega yüzdesi ve Miktarı } & $0-5 \mathrm{~mm}$ & $\% 60-972,75 \mathrm{~kg} / \mathrm{m}^{3}$ \\
\hline & $5-12,5 \mathrm{~mm}$ & $\% 40-662,74 \mathrm{~kg} / \mathrm{m}^{3}$ \\
\hline
\end{tabular}

\section{Araştırma Bulguları}

$\% 5, \% 8, \quad \% 10$ oranlarında katk1 kullanılarak ve katkı kullanılmadan, püskürtme betonu için çimento priz hizlandırıc1 katkı uyum testi ve beton basınç dayanım deneyleri yapılmıştır. Yapılan deneylerde, su/çimento oranı, çimento miktarı ve tipi, agrega miktarı ve özellikleri sabit tutulmuştur.

Priz hızlandırıcı katkı uyum testi için toplamda 6 adet numune hazırlanmıştır. Tablo 4'te farklı yüzdelerde kullanılan priz hızlandırıcı yaş püskürtme betonu için çimento priz hızlandırıcı katkı uyum test değerleri verilmiştir. Şekil 1'de 
farklı yüzdelerde priz hızlandırıcı katkı süreleri verilmiștir.

kullanılarak elde edilen numunelerin priz

Tablo 4. Farkll yüzdelerde kullanılan priz hızlandırıcı yaş püskürtme betonu için çimento priz hızlandırıcı katkı uyum testi

\begin{tabular}{|c|c|c|c|c|c|}
\hline \multicolumn{7}{|c|}{ Püskürtme betonu için çimento priz hızlandırıcı katkı uyum testi } \\
\hline $\begin{array}{c}\text { Numune } \\
\text { No }\end{array}$ & $\begin{array}{c}\text { Katkı } \\
\text { Miktarı } \\
\text { \% }\end{array}$ & $\begin{array}{c}\text { Priz } \\
\text { Başlangıcı } \\
(\mathbf{s n})\end{array}$ & $\begin{array}{c}\text { Priz Bitişi } \\
(\mathbf{s n})\end{array}$ & $\begin{array}{c}\text { Priz } \\
\text { Başlangıcı } \\
\text { Değerlendirme }\end{array}$ & $\begin{array}{c}\text { Priz Bitiş } \\
\text { Değerlendirme }\end{array}$ \\
\hline 1 & 5 & 131 & 269 & Kabul edilebilir & İyi \\
\hline 2 & 5 & 127 & 261 & Kabul edilebilir & iyi \\
\hline 3 & 8 & 81 & 158 & İyi & İyi \\
\hline 4 & 8 & 83 & 164 & İyi & İyi \\
\hline 5 & 10 & 69 & 144 & İyi & İyi \\
\hline 6 & 10 & 67 & 140 & İyi & İyi \\
\hline
\end{tabular}

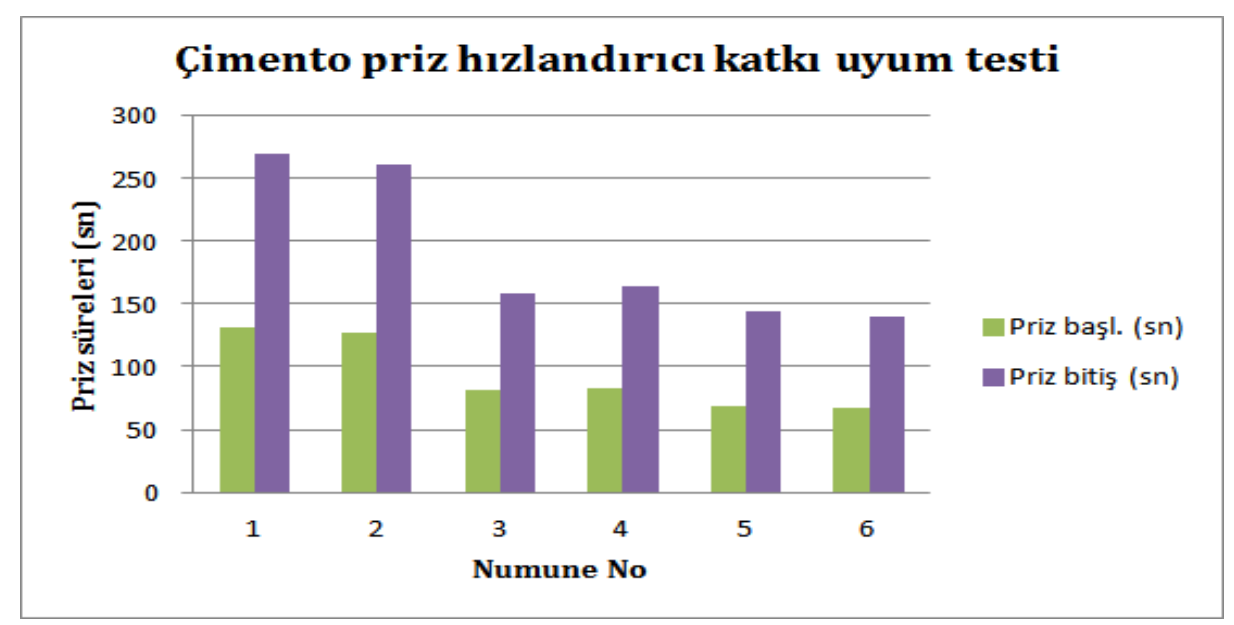

Şekil 1. Farklı yüzdelerde priz hızlandırıcı katkı kullanılarak elde edilen numunelerin priz. süreleri (sn)

Elde edilen değerler Tablo 4 ile değerlendirildiğinde, $\% 5$ oranında priz hızlandırıcı katkı kullanıldığında priz başlangıç süresi kabul edilebilir olarak değerlendirilmektedir. \%5 katkı kullanımı için priz bitiş süresi, $\% 8$ ve $\% 10$ katk1 kullanımındaki priz başlangıç ve priz bitiş süreleri ise iyi olarak değerlendirilmektedir.
$150 * 150 * 150 \mathrm{~mm}$ boyutlarında küp katkısız kontrol numuneleri ve $\% 5, \% 8$ ve $\% 10$ oranlarında priz hızlandırıcı katkı kullanılarak elde edilen numuneler üzerinde 3,7 ve 28 günlük basınç dayanımı deneyi yapılmıştır.

Tablo 5'te katkısı kontrol numuneleri için 3,7 ve 28 günlük basınç 
dayanım değerleri yer almaktadır. Tablo 6'da \%5 katkı miktarı için 3, 7 ve 28 günlük basınç dayanım değerleri yer alırken, Şekil 2'de katkısız numune ile \%5 katkılı numune basınç dayanımı gün grafiği yer almaktadır.

Tablo 7'de, \%8 katkı miktarı için 3, 7 ve 28 günlük basınç dayanım değerleri yer alırken, Şekil 3'te katkısız numune ile \%8 katkılı numune basınç dayanımı gün grafiği yer almaktadır. Tablo 8 'de $\% 10$ katkı miktarı için 3, 7 ve 28 günlük basınç dayanım değerleri yer alırken, Şekil 4'te katk1sız numune ile \%10 katkılı numune basınç dayanımı gün grafiği yer almaktadır.

Tablo 5. Katkısız kontrol numuneleri için 3, 7 ve 28 günlük basınç dayanım değerleri

\begin{tabular}{|c|c|c|c|}
\hline $\begin{array}{c}\text { Katkı } \\
\text { Miktarı \% }\end{array}$ & $\begin{array}{l}\text { Süre } \\
\text { (Gün) }\end{array}$ & $\begin{array}{c}\text { Basınç } \\
\text { Dayanım } \\
\text { Değerleri } \\
\left(\mathrm{N} / \mathrm{mm}^{2}\right)\end{array}$ & $\begin{array}{c}\text { Ortalama } \\
\text { Basınç } \\
\text { Dayanım } \\
\text { Değerleri } \\
\left(\mathrm{N} / \mathrm{mm}^{2}\right)\end{array}$ \\
\hline \multirow{9}{*}{$\% 0$} & \multirow{3}{*}{3} & 35,1 & \multirow{3}{*}{36,7} \\
\hline & & 38,8 & \\
\hline & & 36,7 & \\
\hline & \multirow{3}{*}{7} & 41,0 & \multirow{3}{*}{43,2} \\
\hline & & 44,8 & \\
\hline & & 43,9 & \\
\hline & \multirow{3}{*}{28} & 50,3 & \multirow{3}{*}{53,1} \\
\hline & & 55,1 & \\
\hline & & 54,0 & \\
\hline
\end{tabular}

Tablo 6. $\% 5$ katkı miktarı için 3, 7 ve 28 günlük basınç dayanım değerleri

\begin{tabular}{|c|c|c|c|}
\hline $\begin{array}{c}\text { Katk1 } \\
\text { Miktar1 } \\
\%\end{array}$ & $\begin{array}{c}\text { Süre } \\
\text { (Gün) }\end{array}$ & $\begin{array}{c}\text { Basınç } \\
\text { Dayanım } \\
\text { Değerleri } \\
\left(\mathrm{N} / \mathrm{mm}^{2}\right)\end{array}$ & $\begin{array}{c}\text { Ortalama } \\
\text { Basınç } \\
\text { Dayanım } \\
\text { Değerleri } \\
\left(\mathrm{N} / \mathrm{mm}^{2}\right)\end{array}$ \\
\hline \multirow{9}{*}{$\% 5$} & \multirow{3}{*}{3} & 26,1 & \multirow{3}{*}{27,0} \\
\hline & & 27,5 & \\
\hline & & 27,4 & \\
\hline & \multirow{3}{*}{7} & 34,9 & \multirow{3}{*}{36,7} \\
\hline & & 37,8 & \\
\hline & & 37.3 & \\
\hline & \multirow{3}{*}{28} & 41,7 & \multirow{3}{*}{43,5} \\
\hline & & 44,8 & \\
\hline & & 44,0 & \\
\hline
\end{tabular}

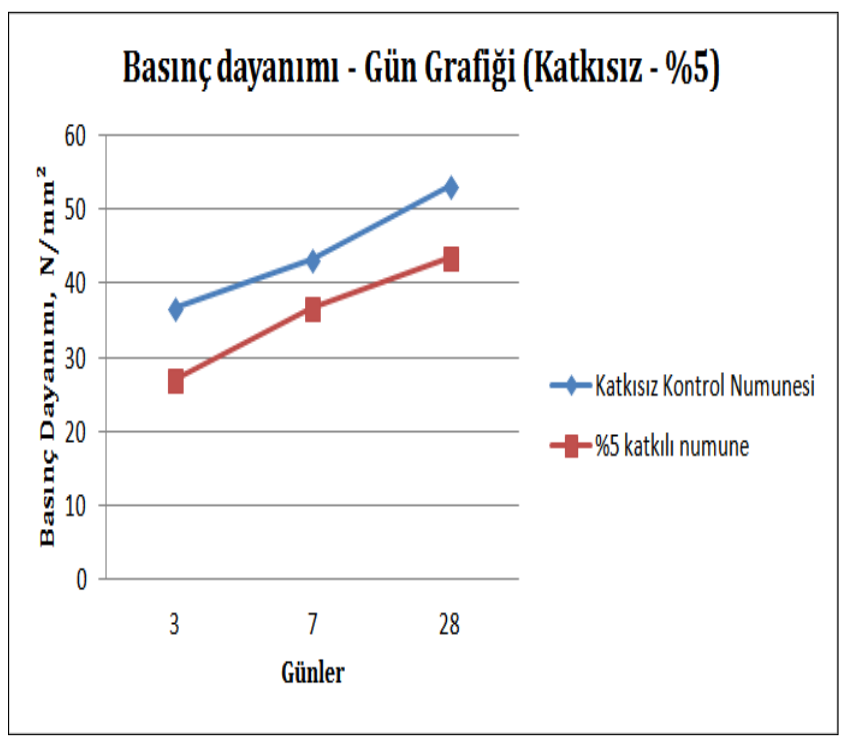

Şekil 2. Katkısı numune ile \%5 katkulı numune basınç dayanımı gün grafiğ $i$ 
Tablo7. $\% 8$ katkı miktarı için 3, 7 ve 28 günlük basınç dayanım değerleri

\begin{tabular}{|c|c|c|c|}
\hline $\begin{array}{c}\text { Katkı } \\
\text { Miktarı } \\
\%\end{array}$ & $\begin{array}{l}\text { Süre } \\
\text { (Gün) }\end{array}$ & $\begin{array}{c}\text { Basınç } \\
\text { Dayanım } \\
\text { Değerleri } \\
\left(\mathrm{N} / \mathrm{mm}^{2}\right)\end{array}$ & $\begin{array}{c}\text { Ortalama } \\
\text { Basınç } \\
\text { Dayanım } \\
\text { Değerleri } \\
\left(\mathrm{N} / \mathrm{mm}^{2}\right)\end{array}$ \\
\hline \multirow{9}{*}{$\% 8$} & \multirow{3}{*}{3} & 23,8 & \multirow{3}{*}{23,3} \\
\hline & & 22,5 & \\
\hline & & 23,6 & \\
\hline & \multirow{3}{*}{7} & 32,6 & \multirow{3}{*}{31,5} \\
\hline & & 30,2 & \\
\hline & & 31,7 & \\
\hline & \multirow{3}{*}{28} & 38,7 & \multirow{3}{*}{37,9} \\
\hline & & 36,7 & \\
\hline & & 38,4 & \\
\hline
\end{tabular}

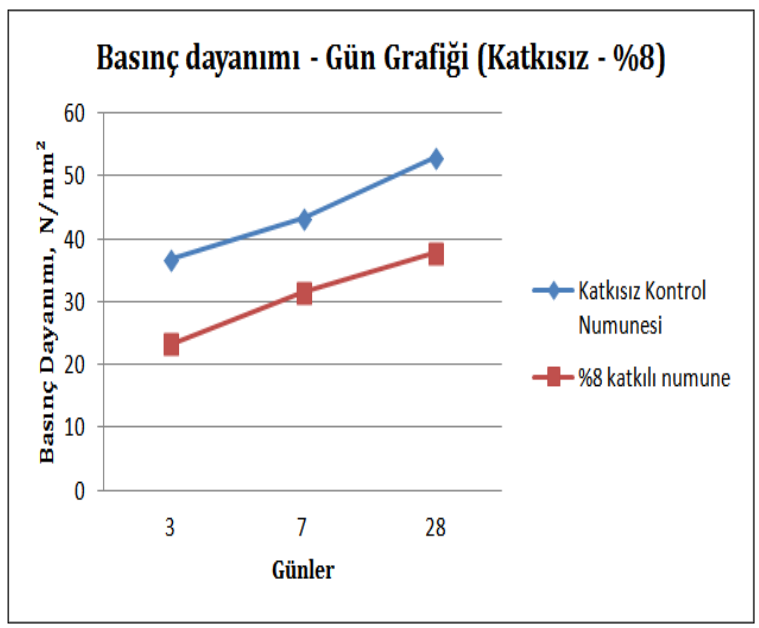

Şekil 3. Katklsız numune ile \%8 katkılı numune basınç dayanımı gün grafiği
Tablo 8. \%10 katkl miktarı için 3, 7 ve 28 günlük basınç dayanım değerleri

\begin{tabular}{|c|c|c|c|}
\hline $\begin{array}{c}\text { Katkı } \\
\text { Miktarı } \\
\%\end{array}$ & $\begin{array}{l}\text { Süre } \\
\text { (Gün) }\end{array}$ & $\begin{array}{c}\text { Basınç } \\
\text { Dayanım } \\
\text { Değerleri } \\
\left(\mathbf{N} / \mathbf{m m}^{2}\right)\end{array}$ & $\begin{array}{c}\text { Ortalama } \\
\text { Basınç } \\
\text { Dayanım } \\
\text { Değerleri } \\
\left(\mathrm{N} / \mathbf{m m}^{2}\right)\end{array}$ \\
\hline \multirow{9}{*}{$\% 10$} & \multirow{3}{*}{3} & 20,4 & \multirow{3}{*}{20,1} \\
\hline & & 20,8 & \\
\hline & & 19,4 & \\
\hline & \multirow{3}{*}{7} & 28,0 & \multirow{3}{*}{28,0} \\
\hline & & 28,8 & \\
\hline & & 27,2 & \\
\hline & \multirow{3}{*}{28} & 32,3 & \multirow{3}{*}{32,5} \\
\hline & & 33,9 & \\
\hline & & 31,4 & \\
\hline
\end{tabular}

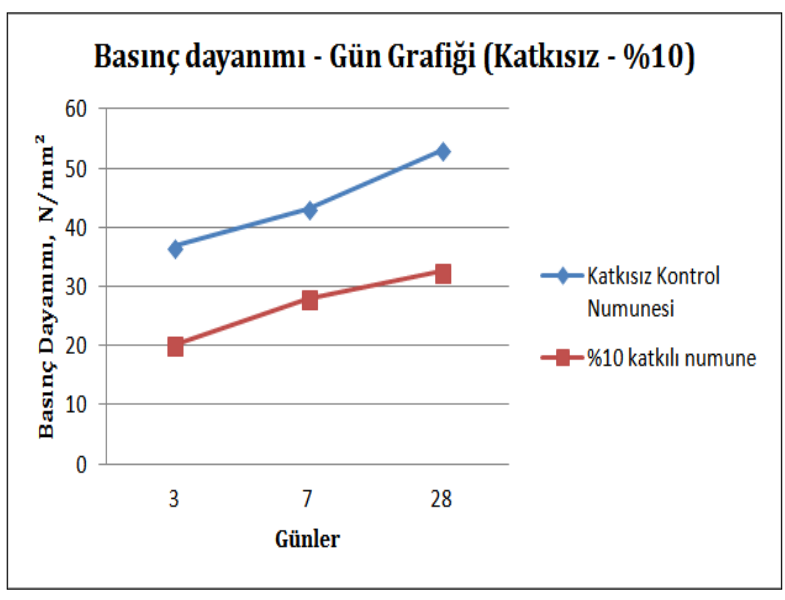

Şekil 4. Katkısı numune ile \%10 katkılı numune basınç dayanımı gün grafiği

Farklı katkı yüzdeleriyle yapılan deneylerde elde edilen 28 günlük basınç dayanım değerleri, Tablo 1'deki değerlere uygun olmalıdır. C 20/25 püskürtme betonu olarak tasarlandığı için bu beton sınıfının 28 günlük bireysel minimum dayanım ve 3 adet numuneden oluşan 
grubun ortalama minimum değeri şartnamesi değerine uyulmaktadır. $\mathrm{Bu}$ standartlara uygun olmalıdır. Kullanılan değerler Tablo 9'da verilmiştir. tüm katk1 yüzdelerinde Karayolu Teknik

Tablo 9. Farkı yüzdelerde kullanılan katkı miktarı için 28 günlük basınç dayanım değerleri değerlendirmesi

\begin{tabular}{|c|c|c|c|c|c|}
\hline $\begin{array}{l}\text { Katk1 } \\
\text { Miktarı } \\
\%\end{array}$ & $\begin{array}{l}\text { Süre } \\
\text { (Gün) }\end{array}$ & $\begin{array}{l}\text { Basınç } \\
\text { Dayanımı } \\
\left(\mathrm{N} / \mathrm{mm}^{2}\right)\end{array}$ & $\begin{array}{l}\text { Karayolu Teknik } \\
\text { Şartnamesi } \\
\text { (C 20/25) [10] }\end{array}$ & $\begin{array}{l}\text { Ortalama } \\
\text { Basınç } \\
\text { Dayanımı } \\
\left(\mathrm{N} / \mathrm{mm}^{2}\right)\end{array}$ & $\begin{array}{l}\text { Karayolu } \\
\text { Teknik } \\
\text { Şartnamesi } \\
\text { (C 20/25) [10] }\end{array}$ \\
\hline \multirow{3}{*}{$\% 5$} & \multirow{3}{*}{28} & 41,7 & \multirow{3}{*}{$>19,0$} & \multirow{3}{*}{43,5} & \multirow{3}{*}{$>21,5$} \\
\hline & & 44,8 & & & \\
\hline & & 44,0 & & & \\
\hline \multirow{3}{*}{$\% 8$} & \multirow{3}{*}{28} & 38,7 & \multirow{3}{*}{$>19,0$} & \multirow{3}{*}{37,9} & \multirow{3}{*}{$>21,5$} \\
\hline & & 36,7 & & & \\
\hline & & 38,4 & & & \\
\hline \multirow{3}{*}{$\% 10$} & \multirow{3}{*}{28} & 32,3 & \multirow{3}{*}{$>19,0$} & \multirow{3}{*}{32,5} & \multirow{3}{*}{$>21,5$} \\
\hline & & 33,9 & & & \\
\hline & & 31,4 & & & \\
\hline
\end{tabular}

\section{Sonuç}

Çalışmada, tünellerde kullanılan priz hızlandırıcı katkılar için yapılan deneysel çalışmalar ve değerlendirmeler incelenmiştir. Deneysel çalı̧̧malar sonucunda elde edilen verilerin değerlendirilmesi aşağıda yer almaktadır.

- Deneylerde kullanılan \%10 priz hızlandırıcı katkı miktarı, priz süresini oldukça kısaltmaktadır. Priz süresinin bu denli kısalması, uygulama açısından zorluklar oluşturmaktadır. $\mathrm{Bu}$ sebepten $\% 10$ katkı miktarı, elde edilen priz süreleri göz önüne alındığında uygunluk sağlamamaktadır.

- $\% 5$ priz hizlandırıcı katkı malzemesi kullanılması durumunda, priz süresi değerlendirme tablosuna göre ilk priz süresi kabul edilebilir olarak değerlendirilmişstir.

- Tüm yüzdeler incelendiğinde yapılan deney sonuçlarına göre $\% 8$ priz hızlandırıcı katk1 miktarının en uygun sonucu verdiği gözlemlenmiştir.

- $\quad$ Optimum olarak belirlenen \%8'lik priz hızlandırıcı katkı, katkısız kontrol numunesine göre değerlendirilirse \%29'luk 
bir basınç dayanımı azalmasına neden olmuştur.

- $\quad$ Elde edilmiş olan bu sonuç, yapılan araştırma sonuçları ile kıyaslanmıştır. Priz Hızlandırıcı katkılar, katkının dozaj oranına, çimento kimyasına ve kendi kimyasına bağlı olarak farklı etkilere sahiptir. Birçok hızlandırıcı katkı, çimentonun ve hızlandırıcının uyumuna bağlı olarak 28 günlük dayanımı $\% 25-40$ oranında azaltmaktadır [18].

- $\% 8$ oranında kullanılan priz hızlandırıcı katk1 kullanımı, EFNARC Avrupa Püskürtme Beton Şartnamesi (1996) Ek 1, Madde 6.3'te ve Karayolu Teknik Şartnamesinde (2013) belirtilen priz başlama ve priz sona erme sürelerinde belirtilen priz değerlendirme koşullarına göre, 2 dakikanın altında olan 1 dakika 52 saniye değeri elde edilen ilk priz değeri ideal bir sonuçtur. 1 dakika 52 saniyeden kısa olacak ilk priz süreleri, beton dayanımını daha da azaltacak ve şantiyede püskürtme beton uygulamasını zorlaştıracaktır. Son priz değeri olarak elde edilen 2 dakika 35 saniye değeri de, 6 dakikadan düşük bir zamandır ve "iyi" olarak değerlendirilmektedir. [19]

\section{Teşekkür}

$\mathrm{Bu}$ çalışma, 4383-YL1-15 numaralı proje ile Süleyman Demirel Üniversitesi Bilimsel Araştırma Projeleri Yönetim
Birimi Başkanlığı tarafından desteklenmiştir.

\section{Kaynaklar}

[1] ACI Committe 506, 1966. Recommended Practice for Shotcrete (ACI 506 - 66). Shotcreting, ACI SP-14.

[2] TS 11747, 1995. Püskürtme Beton (Shotcrete) Yapım, Uygulama ve Bakım Kuralları. Türk Standartları Enstitüsü, Birinci Bask1, ICS 91.100.30. Ankara.

[3] Arıoğlu, E., Yüksel, A., Yılmaz, A. O., 2008. Püskürtme Beton Bilgi Föyleri Çözümlü Problemler. TMMOB Maden Mühendisleri Odası Yayın No: 142, İstanbul.

[4] Aka, İ., ve Celep, Z., 1978. Püskürtme Beton ve Uygulaması. İstanbul Teknik Üniversitesi Mühendislik ve Mimarlık Fakültesi, Betonarme, Ahşap ve Çelik Yapılar Kürsüsü, İstanbul.

[5] Özdoğan, M. V., 2009. Yer altı Yapılarında Püskürtme Beton ve Dolgu Dizayn. Dokuz Eylül Üniversitesi Fen Bilimleri Enstitüsü Yüksek Lisans Tezi, İzmir.

[6] Sümer, T., 1994. Püskürtme Beton Malzeme, Ekipman, Katkı Seçim Kriterleri ve Maliyet Optimizasyonu, TMMOB İnşaat Mühendisleri Odası, İzmir Şubesi Haber Bülteni, Sayı: 56, 18-21s., İzmir.

[7] ACI Committe 116, 1990. Cement and Concrete Terminology, ACI 116R-90, SP19 (90), p.54. American Concrete Institute, Detroit.

[8] Yi S T, Heo G, 2010. Experimental study on the setting time of cement paste mixed with accelerating admixtures based on C(3)A, Advances in cement research 22(3): 149-155. 
[9] Bourchier, F., B., 1990. Practical Considerations of Shotcrete in an Underground Mining Enviroment. Toronto Üniversitesi Doktora Tezi, Toronto.

[10] TS 706 EN 12620, 2006. Beton Agregaları. Türk Standartları Enstitüsü, Ankara.

[11] Karayolu Teknik Şartnamesi, 2013. T.C. Ulaştırma Denizcilik ve Haberleşme Bakanlığı, Karayolları Genel Müdürlügü, Ankara.

[12] EFNARC, 1999. European Specification for Sprayed Concrete Guidelines, ISBN. 0952248360, p28.

[13] Melbye, T., 2006, Sprayed Concrete for Rock Support. UGC International. Division of Degussa Construction Chemicals (Switzerland) Ltd. 11th Edition, Switzerland.

[14] Levent, Y., Kalmış, M., 2014. Püskürtme Beton Uygulamalarında Yaşanan Sorunlar ve Çözümleri, İksa Kurs Notları, İstanbul.

[15] Neville A M, 2011. Properties of concrete, Pearson Education Limited, England.

[16] EFNARC, 1996. European Specification for Sprayed Concrete, UK.

[17] Yıldırım, H., Uyan, M., Kemerli, K., 1996. "Priz Hızlandırıcılı Püskürtme Beton Katkılarının Dayanıma Etkisi”, 4. Ulusal Beton Kongresi, TMMOB İnşaat Mühendisleri Odas1, İstanbul.

[18] U.S. Army Corps of Engineers, Engineering and Design Standard Practice for Shotcrete. Department of the Army U.S, 2005. Army Corps of Engineers, Distribution Restriction Statement. CECW-EG Engineering Manual No: 11102-2005, Washington.
[19] Erdoğan T Y, 2016. Beton, ODTÜ Geliştirme Vakfı Yayıncılık ve İletişim A.Ş., Ankara. 